\title{
Disoriented Temporalities: Narrating postcolonial Progress(ions) in the Novels of Ngugi wa Thiong'o and Ahmadou Kourouma.
}

\author{
Gilbert Ndi Shang \\ Bayreuth Academy of Advanced African Studies \\ University of Bayreuth
}

\begin{abstract}
The African novel is one of the prescient prisms through which social, cultural and political transformations on the continent can be apprehended. As such, it is not merely a site of reflection on the society, but a pole of constructive imagination on the intricate link between the past and the present, the global and the local, the ephemeral and the enduring. In this paper, we examine artistic representations of "moments of change" and historical progression in Ngugi's Wizard of the Crow and Kourouma's En Attendant le Vote des Bêtes Sauvages. Through diverse narrative techniques, characterization and thematic articulations, we examine how the two novels expose the 'disturbed movement' of historical "progression"in the postcolony wherein the new era of hope often carries shades of the past and seeds of future disillusionment. Transitions therefore become instances where past practices are embedded and complexified in the present. However, despite the tendency towards historical determinism in the two novels whereby any moment of change is fictionalized as a repetition of history, both authors, through different artistic forms and with different intensity, expound an openended and equivocal future where hope is juxtaposed with despair and optimism contrasted with uncertainty.
\end{abstract}

Key words: temporality, subversion, memory, progress, transition

\section{INTRODUCTION AND THEORETICAL INTERROGATIONS}

The African novel is one of the prescient and memorial prisms through which social, cultural and political transformations on the continent can be apprehended. As such, it is not merely a site of reflection on the society, but a pole of constructive imagination on the intricate link between the past and the present, the global and the local, the ephemeral and the enduring as far as African cultures, politics and histories are concerned. This article discusses creative representations and interrogations of transitional moments in the works of African authors in the light of the aesthetic of change, that is, recurrent forms of narration that are noticeable in artistic renditions of political change in Africa. In this regard, the present article analyzes the dialectical relationship between the text as an aesthetic project and its transfiguration of political reality into its structures of meaning.

Before analyzing the artistic narrations and interrogation of notions of progress in the texts of Ahmadou Kourouma and Ngugi wa Thiong'o, it is necessary to underline some of the fundamental considerations within "postcolonial" theory with regard to temporal connotations of the notions of progress and progression. In other words, it is important to examine the implications of the term 'post'coloniality as a marker of progress beyond colonialism. The prefix 'post' as a semantic fragment refers to the surpassing, aftermath, distancing from a process, phenomenon or event that is characteristic of the past. The major anxiety around the terminology is its simplistic division of time along a linear horizontal paradigm of past, present and future. The prefix "post" prima facie denotes the presumption of "temporally coming after and ideologically, supplanting" colonialism (Loomba 1998:7). Loomba asserts that it is the 
ideological sense of the word which is contestable for a society can be both "post-colonial (in the sense of being formally independent) and neo-colonial (in the sense of remaining economically and/or culturally dependent) at the same time" (1998:7). The controversy of the concept therefore lies in the fact that though formally decolonized, formerly colonized societies still undergo new forms of colonization, internally and externally. As Bhabha puts it, the inherent ironies and paradoxes that characterize 'post' - colonial criticism come from the fact that 'the 'beyond' is neither a new horizon, nor leaving behind of the past. Beginnings and endings may be the sustaining myths of the middle years" (1994:1). It is this "disturbance" of the progression of time from a secured and disavowed past to a redeemed present/future that accounts for the interrogation of notions of progress, change and modernity in postcolonial texts. Instead of regarding transition as a 'beyond', Bhabha's criticism suggests a more complex form of temporality that underlines the hybridity of the postcolonial historical moment.

The prefix "post" also pre-supposes an underestimation of internal layers of oppression and alienation within the colonized societies that have replaced the formal and former colonizer/colonized relationship. Some of these patterns of internal domination can either be traced back to pre-colonial and colonial societies or may be analyzed as recent phenomena, coming after independence. Post-colonial literature therefore does not only seek to address the colonial and neo-colonial situation, but also to reveal often overlooked but persistent patterns of dominance and subjugation within and amongst colonial and neo-colonial societies. One of the most poignant and comprehensive criticism of post-colonialism is contained in Anne McClintock's "Angels of Progress: The Pitfalls of the Term 'Post-colonialism."' McClintock engages in a critical interrogation of the prefix 'post' when interpreted as 'coming after' colonialism. In her view, colonialism is not a thing of the past for "Colonialism returns at the point of its disappearance" (2010:629). As such, she argues for the primacy of power relations over temporal movement. The 'post' merely underlines a temporal relation, ignoring the power imbalance that still characterizes the relationship between colonial masters and their neocolonies (2010:633). McClintock makes an epistemological attack on the linear representation of time and underscores that "alternative times experience of time, histories and causalities are required to deal with the complexities that cannot be served under the single rubric 'postcolonialism'"(2010:633-4). Such alternative conceptions generally interrogate the 'pastness' of the past and expose practices that traverse temporal demarcations of past, present and future. As a critique of linear temporality that marks the movement of the Angel of Progress, alternative and subversive timelines are created that are both circular and secular. She goes ahead to assert that "most problematically, the historical rupture suggested by the preposition "post"- belies both the continuities and discontinuities of power that have shaped the legacies of the formal European and British colonial Empires (2010:633). It is due to such continuities and discontinuities that representations of the postcolonial State and colonial States refer to similar metaphorical texts with regard to creative subversion of subject formation and hegemonic construction under the postcolonial dispensation. The paradox of postcolonial condition on the configuration of the postcolonial novel is fundamental. The normalcy of time as a division between past, present and future becomes a subject of aesthetic innovation and complexity in the novels under examination. This point is important as it accounts for the various experimentation of temporal representation in postcolonial novels that posit as a contestation of the ideology of time itself. The (ab)use of particular verbal tense in postcolonial text is not a mere grammatical but also an ideological choice. In the writing of resistance literature, various experiences of time in the expression of the post-colonial conditions are crucial. On the question of postcolonial texts and the transfiguration of the notion of time, Said refers to the "disquiet" of what T S Eliot calls the 'cunning history and contrived corridors' of time - the wrong turns, the overlap, the senseless repetition..." (1984:281) which must be 
factored into the narrative process. This underlines the examination of postcolonial texts as propitious spaces for the disorientation of linear temporality as a subversion of totalizing notions of progress.

The novels of the Ivorian author Ahmadou Kourouma and the Kenyan writer and critic Ngugi wa Thiong'o provide appropriate platforms on which to capture and interrogate aspects of postcolonial notions of progress. Ahmadou Kourouma and Ngugi wa Thiong'o are perennial voices on the African literary scene especially with regard to the novelistic genre. For close to half a century, their works have continued to solicit sustained critical attention in scholarly circles. While critics on Kourouma's works have often focused on the linguistic materiality of his texts (Koné 2007; Ndiaye 2007), Ngugi's novels, plays and critical works have continued to draw critical engagement especially with regard to their more or less overt revolutionary tonality (Indangasi 1997; Elliot 2003). Whatever their peculiarities, one of the unifying traits in both authors' works is their continuous engagement with socio-political issues of African societies from a longue durée perspective. As such, a recurrent trend in their works is the figuration of the interconnections between historical antecedence and actuality/contemporaneity wherein the realities of the past are dialectically refracted through the mirror of the present. It is from this analytical disposition that we examine Kourouma's En Attendant le Vote des Bêtes Sauvages and Ngugi's Wizard of the Crow, two artistic re-creations of socio-political realities in post-colonial African societies.

\section{Kourouma's donsomana for postcolonial leaders: On the circularity of temporal movements.}

The central plotline of Kourouma's En Attendant le Vote des Bêtes Sauvages represents the genealogy and exploits of the hunter cum president Koyaga of the Republic of Gulf as narrated by his "praise singer", Bingo and his apprentice/companion, Tiekoura. In line with the tenets of the epic song, Koyaga is portrayed as an exceptionally brave character, possessing magical powers and destined for "greatness". However, his hunting dexterity is intertwined in the narrative with the shrewdness with which he emasculates his foes who are, in his deluded imaginary, less worthy than beasts. The manner of his accession to power, after the assassination of his predecessor Fricassa Santos, and later his fellow coup plotters (Tima, Ledjo and Crunet), heralds the form of the regime of violence that he later on institutes in the postindependence Gulf Republic. The narrative form used in the text reveals a peculiar conception of historical movement that questions and challenges the discourse of progress propagated by the forces of domination in the political scene.

The structure of Kourouma's text constitutes the primary entry into his subversive aesthetics. The story takes the form of a donsomana, a traditional Malinke purificatory song performed in honour of great and accomplished hunters (En Attendant, 21). It moves forth and back in a systematic, recurrent vicious cycle. This retour-en-arrière, a major characteristic of the epic, underlines the nature of the story that is being told in the text in which the past continues to reproduce itself in the present (Borgomano 2000:29). There are neither true beginnings nor definite endings in this novel. This antinomic narrative form constitutes a structural subversion of Koyaga's notion of progress and his claimed indispensability in the redemption of the Republic of Gulf and Africa as a whole from its dehumanizing past: "Sans lui, le pays retomberait dans la misère, l'Afrique retournerait à la colonisation, à l'esclavage, à sa sauvagerie congénitale." (Without him, the country would recede into misery, Africa would fall back to colonization, to its congenital barbarism) (En Attendant, 275). Koyaga's rule thrives on the same "civilizing mission" that characterized certain colonial conceptualizations and othering of the subject as a patient that has to be rescued from his suicidal instincts. The donsomana turns out then to be a satire and a veritable chant of indictment where the falsely euphonic life-story of Koyaga written by his official biographers is subverted by the insider- 
narrative of the sora. Though Koyaga, the protagonist stands as the figural character through whose eyes events are perceived and judged, the sora remains the narrative voice that betrays and ridicules his jaundiced perception of reality. The voice of the sora thus achieves a mimic effect - that of subverting the master-perspective of the ruler while simulating his (Koyaga's) authoritative voice. This is particularly related to Koyaga's use of violence against his enemies.

Koyaga's treatment of his antagonists reflects an idiosyncratic cruelty, a peculiar form of "necro-power" (Mbembe 2000:32) based both on superstitious traditional ritual and modern political violence which seek to dehumanize and annihilate both the somatic and spiritual self of the "other". The narrator's rendering of the following scene captures the orgy of Koyaga's violent practice:

Tranquillement les tirailleurs déshabillèrent le président; l'homme était lui aussi incirconcis [...] C'est sur le vif que Koyaga procéda à l'ablation du sexe et à l'introduction du pénis et des bourses ensanglantées entre les dents, dans une bouche tenue ouverte par les bras de fer de deux tirailleurs hilaires. (En Attendant, 112)

(The musketeers slowly undressed the president; he was also uncircumsized [...] Koyaga immediately went on to ablate his sexual organ and insert his penis and his testises between his teeth into the mouth drawn open by the hands of the two hilarious musketeers)

Being uncircumcised reduces his victim to the level of an effeminate man, incomparable to the phallic prowess of Koyaga. Kourouma's dexterous use of the imagery of hunting as an underlying metaphor in the text portrays the eccentric and syncretic mindset that characterizes Koyaga's practice of political victimization. His imaginary conception of power is informed by long traces of the past to which he is heir. This concurs with Mbembe's claim that certain forms of post-colonial violence are a hybrid conjunction of imported tactics and a perverted ancestral imaginary (2000:96). It is however important to note that somatic violence is employed here both to ethical and aesthetic effects and it is the latter that explains the ubiquity of violence and blood in the text. His use of detailed and picturesque description of violent scenes conforms to what Richard K. Priebe characterises as "copia" and "syndesis", rhetorical figures used to amplify the numbing effect of violence through an abundance of detail (Priebe 2005:8). In effect, this stylistic device should enable us appreciate the use of violence from a symbolic and cathartic perspective.

It is through the devices of copia and syndesis that repetitions in the text can be understood. Such repetitions include the parallel texts that recount the biographies of the various dictators in the text, anaphoric representations that enhance the musicality of the donsomana performance as well as underline the similarity between Koyaga and his counterparts. The narrator re-hashes in a rather monotonous but purposeful manner, the feigned miraculous rescue of Koyaga in his string of plane crashes and the mechanistic reactions of his fellow dictators (En Attendant 254, 287). Due to the nature of recurrences in the text, it is difficult to assert if the repeated events are mere verbal re-iterative creations of singular incidents or a faithful recounting of repeated events. This blurred line represents the role of confabulation in fictional narration whereby the power of discourse overshadows and clouds the veracity of the primary story. As Bisanswa asserts, in the epic, "there is exaggeration of facts and the structure of the epic itself reflects this pre-eminence of music over text because to everyone of the main themes developed in the story, there is a corresponding musical sentence" (2007:4). In En Attendant discourse creates reality as well as it displaces it. This leads to a structure 
characterized by splintered and dispersed narratives. The text is therefore not a single but a series of embedded and competing donsomanas, narrating the lives of several dictators who, though claiming to be collaborative comrades, are in effect vying against each other in their bid to distend both traditional and modern forms of absolute power. The distortion of the linear narrative is a critique of the horizontal movement of history along a progressive paradigm. Kourouma's non-linear narrative is thus an aesthetic representation of the interrogation of logical progression as a means of conceiving discourses of change and transitions.

In as much as the narrative is laterally dispersed, it nevertheless retains vertical unity through genealogical and filial metaphor of the "mother". The mother image is a symbolic aspect of this text that need not be overemphasized. Though he is presented as a virile president and symbol of phallic authority, Koyaga is ironically tied to the umbilical cord of his mother Nadjouma, who maintains a sinister presence in the text. Despite the fact that the narrator explains the influence of Nadjouma by referring to the primordial role of the mother in the life of a child in the traditional society represented in the text, there is evidence to purport that there is more to the mother image. Bingo's explanation therefore glosses over the political undertones suggested by the mother image. The innuendo of incest between Koyaga and Nadjouma is repeated severally in the text. Bingo tells Koyaga that "Les relations entre vous et votre maman sont trop étroites. On vous accuse d'amour incestueux. Accusation à laquelle vous ne répondez jamais" (En Attendant, 279). (The bond between you and your mother is too strong. People accuse you of incestuous love but you never respond to such accusations). The subject of his relationship with his mother, Nadjouma is never addressed in public (except through rumours), yet without her magical influence, his rule is bound to wane. A mysterious presence whose role can only be clarified through the magical and superstitious mode that underlies Bingo's narrative, Nadjouma can be disputably considered the heroine of the text. Her mystical disappearance is responsible for the purificatory ceremony on which the text is constructed. The identity of Nadjouma becomes inseparable from and inherent in that of his son. The worship of the mother, which prevents the progeny from developing a separate identity, is a revealing metaphor in both texts. Though it would be too sweeping to consider postcolonial regimes as mere puppets of the former colonial master (Garnier 2009:16), Kourouma's use of the mother/son relationship could be a hyperbolical representation of neocolonial relationship that deconstructs the beyond" of the postcolonial. Writing on the colonial situation, Mbembe asserts that a filial relationship exists between the colony and the motherland, a relationship which is inherited by the post-colonial nation-state (2000: 57). Though the narrator uses cultural motivation to account for the overwhelming presence of Nadjouma behind the scenes, the implicit political undertone is quite evident in other parts of the text (En Attendant 77, 78) where authorial intrusion reveals the continuous though hidden influence of the former colonial master in the politics of the Gulf Republic and the other congenial dictatorships in the text. Kourouma's artifice is revealed in his dexterous interweaving of layers of discourses into the filial and genealogical back-cloth against which this text is set.

This filial analogy is again seen in Bingo's narration of the national conference that is held to negotiate the democratic transition that follows the civic demonstrations against Koyaga. The narrator's rendering of the politics of the national conference brings to light the re-staging of history, a history of betrayal and usurpation of the cause for change. Though the victims of the revolution that takes place at the end of the text are downtrodden subjects of the Gulf Republic, those who benefit from the cause are a new breed of immigrants who have been leading luxurious lives in the Diaspora while the dispossessed masses endured untold destitution under the dictatorship of Koyaga. Those who pose as youth leaders do not hesitate to betray the system when they are offered bribes by the system in place. The vicious cycle of the subject classes continue while some privileged members of the youth groups join the government forces. The betrayal of the pre-colonial times is therefore carried over to transitions in the 
post-colony. Such a representation reflects Achille Mbembe's interrogation of the progressive connotation of the "post- » in the post-colony which he describes as "un emboîtement des présents, des passés et des futurs qui tiennent toujours leur propre profondeur d'autres présents, passés et futurs, chaque époque portant, altérant et maintenant tous les précédents"(2000:36). (an embededness of presents, pasts and futures which always retain the depth of other presents, pasts and futures with each epoch carrying, altering and maintaining all the preceding ones). In effect, Kourouma uses genealogical imagery as a trope to present the re-emergence of past realities in contemporary post-colonial societies. The genealogical trope of recurrence is re-enforced in the text by the narrative tonality of the sora.

Bingo's narrative tonality converts the dramatic climax in the text into an inconsequential anticlimax where the revolt against Koyaga fails. The sudden uprising of the unemployed youth, the bilakoros that arouses hope as a moment where the past would give way to the future, is saddled with contradictions and the expectations raised by the national conference turn out to be chimerical. After the highly rhythmic and pseudo-martial recounting of the stand-off between the disenchanted youth and Koyaga's wild dogs (les lycaons), the narrator's tone turns sarcastic. The image of "revolutionaries" En Attendant 327) cedes into that of "dancers", portraying the theatricality of the moment and its fulfillment of a circular progression. Behind the drama and the violence, lies the unhappy continuity of past norms and practices. The transition from the class of the "oppressed" to that of "oppressors" is dramatically and graphically represented. The revolution is therefore betrayed at the dawn of the supposedly new beginning and the bilakoros are portrayed as a new set of actors entering the circus of performance (En Attendant 296). As such, Kourouma's text does not only portray societies in a flux, but also constitutes a literary consideration of the phenomenal stability of debased political habits that resist even apparently decisive upheavals. In the narrative, the continuity of the past seems to be a question of fatality and pre-ordination. This can be illustrated through the nature of proverbs that run through the text.

The reproduction of the past is evident in Kourouma's use of proverbial expressions which constitute part of the cultural aesthetics and the enunciatory medium through which this text is woven. As Bingo claims, "Le proverbe est le cheval de la parole; quand la parole se perd, c'est grace au proverbe qu'on la retrouve" (Proverbs are like horses to words, lost words are recovered with the help of proverbs) (En Attendant 41). They are taken as bearers of immanent traditional wisdom as opposed to the hypocritical discourses of Koyaga and his closest minister, Macledio. Each section of the text ends with a series of three proverbs related to a particular theme. This constitutes a reflective interlude for the significance of the ensuing episodes. Though the narrator makes use of a variety of metaphorical analogies in his choice of proverbs, they maintain a thematic unity. Below are some examples:

L'eau ne manque jamais l'ancien chemin de son cours. (28)

(A stream does not miss its course)

L'antilope cob ne bondit pas pour que son petit traine. (28)

(As the kob antelope springs, so does its young one.)

Le singe n'abandonne pas sa queue, qu'il tient soit de sa mère où de son père. (46)

(The monkey does not abandon its tail be it from its mother or father)

L'enfant devient toujours ce qu'est sa mère, possède toujours ce qui appartient à sa mère. (38)

(The child takes after his mother and possesses what belongs to her)

Le veau ne perd pas sa mère même dans l'obscurité (47) 
(Even in the dark, the calf does not lose track of its mother)

L'éléphant meurt mais ses défenses demeurent(47)

(The elephant dies but its trunks remain)

As witnessed in the above examples, proverbs are woven around the metaphors of reoccurrence, fatality, pre-destination, filial continuity and genetic reproduction. They represent the filiation between past and present. If the use of cultural aesthetics through the allegory of hunting and filial genealogy is the macro-structural stylistic device employed by Kourouma to convey the irony of transitions, Ngugi resorts to burlesque political satire in Wizard of the Crow.

\section{Ngugi's the Second Ruler and the Politics of Postcolonial Memory}

The text narrates the power games that take place in the government of the larger-than-life Ruler of the (ironically named) Democratic Republic of Aburiria. In this text, the concepts of change and progress are parodied through the physiological and ideological transformations of the Ruler who entraps the past, the present and the future of his country under his queer political imagination. Just like Koyaga in Kourouma's text, in Wizard of the Crow, the history of the nation is a subsumed sub-plot under the mantle of the Ruler's biographical meta-narrative. The dubious character of transition in the life of the Republic is represented through the metamorphosis of the Ruler. As the narrator says, "the Ruler's rise to power had something to do with his alliance with the colonial state and the white forces behind it" (Wizard 233). As a ploy to obtain the post of vice-president under the First Ruler, he forms a party claiming to improve the working conditions of blacks in higher ranks and to champion the cause of "pastoral communities and fight for their right to wear traditional clothes and carry cultural weapons like bows and arrows, spears and knock-berry clubs" (Wizard 232). The First Ruler, who is supposed to represent the independence of a new nation is just an element of a faulted transition after which the country reverts into the hands of the colonial masters through the corrupt regime of the Second Ruler. He (Second Ruler) symbolizes the continuity of colonialism and is portrayed as the hand tool of the former colonial masters whom he has served as an official in the colonial army. It is therefore not surprising that he and his ministers are accountable not to the citizens but to the authorities of the Global Bank. The text presents a continuation of subjectification that is rendered more complex by the synergy between a corrupt ruling class and the international capitalist system. The change of names of the Ruler's political party symbolizes the regression of his regime into personalized power. Eboussi Boulaga asserts that the magic of power in the post-colony lies in the act of "naming" (1993:114). The constant change of the name of the Ruler's party runs through the text. The name changes from the "United Party" to the "Ruler's party" (234) and with the "democratic transition", it is simply renamed the "Ruling Party". The change only serves to strengthen the Ruler's grip on power. This demonstrates the false nature of progress promised by the Ruler who claims to have given birth to Baby democracy at the end of his self-induced pregnancy. If anything, after the false wind of democratic change, the power of the regime becomes even more personalized and the citizens have to continue under the yoke of his oppression.

The reign of the Second Ruler is ironically presented as transcending human notion of temporal chronology: "His rule had no beginning and no end; and judging from the facts one may well believe that claim. Children had been born and given birth to others and those others to others and so on, and his rule had survived all the generations" (Wizard 5). This hyperbolical assertion reveals the psychic dimension of The Ruler's power which effaces the historical memory of the citizens of the Republic of Aburiria. Time under the Ruler has lost its movement and dynamics and is statically and tightly glued to an eternal "Present", a present which the Ruler considers redemptive whereas the citizens view it as a long night of stasis. Hedged behind a phantasmagorical wall, the Ruler's pathology prevents him from realizing that he is 
being overtaken by events. He finds it difficult to connect with his allies after the end of the Cold War, a period to which he looks with remorse for it was a time when political opponents could be silenced and decimated with impunity so long as they were indiscriminately labeled as "Communists" or "Marxists". When ambassador Gemstone advises him to resign and hand over power to Machokali due to growing discontentment against his rule in Aburiria, the Second Ruler is deeply unnerved and looks back to the Cold War days with nostalgia: "For a moment, he missed the Cold War, when he could play one side against the other. But now, there was no superpower and he knew only how to be wooed, not how to woo" (Wizard 583). The Second Ruler finds it difficult to adapt within the new dispensation where there is a certain respect for human rights. The fact that the pressure for the Ruler to hand over power is coming from a US ambassador whose government had supported the Ruler's hunt against "communists", is tangible proof of the subsequent continuity of the neo-colonial tutelage that had characterized the regime of the Ruler. It shows that the new forms of relations that follow the Cold War would still be marked by imprints of the past. The change is therefore equivocal for it only reconfigures past relations and re-adapts them to new forms of tutelage.

The character Tajirika is very central in the entangled plot lines that make up Wizard of the Crow. As the director of the abortive Marching to Heaven project around which the text is constructed, his will to power is symbolic. When he is appointed as Governor of the Central Bank by the Ruler, he recedes into a hallucinatory state of narcissism: "The sound of the word governor thrilled him, recalling as it did the long line of colonial governors of territorial Aburiria. What had started as a playful act of self-affirmation now became a need, and more and more he found himself conversing with his reflection." In this moment of selfcongratulation, his wife Vinjinia asks him, "Why are you talking to the mirror? Have you forgotten the past?"(Wizard 614). Tajirika's obsession with the mirror symbolizes an internal dialogue with the post-colonial self against the backdrop of colonial trajectory. His fascination with the sound of the word "governor" and the historical memory it retrieves, reveals the subconscious traces of the "concatenation" of the colonial and the postcolonial (Bayart 2010:88) with regard to the practice of power. His summoning of the historical connotation of the title and the epiphany of the aura of greatness it confers, is premonitory to his subsequent seizure of power at the end of the text. Wizard of the Crow therefore posits as a memorial palimpsest which Friedman defines as "the textual unconscious of the published horizontal narrative" (2002:224). The "mirror" represents the refraction of the colonial past in the postcolonial present. It vividly brings out the sedimentation of power practices that straddle across different temporalities. The end of the Ruler's regime, a supposedly climactic point in the text, is narrated listlessly as a non-event due to the resemblance of the new regime to the old:

The climax of Tajirika's ascension to power came when he addressed the nation and pronounced the end of Baby D. A new era of imperial democracy had dawned, he said, and ordered the construction of a modern coliseum on the site once earmarked for Marching to Heaven. (Wizard 754)

The insignia of "change" in the fictional Republic of Aburiria is portrayed in the architectural representations of power. The architectural impressionism that both regimes engage in lends itself to the chronotopic analysis of time and space. The narrator makes use of biblical and historical allusions related to the contest for power through architecture. Architecture in the text acquires the symbolism of a chronotope which Bakhtin defines as "the primary means for materializing time and space", "a centre of concretizing representation" and " a force giving body to the entire novel"(Richardson 2002:22). From the chronotope of Marching to Heaven to the modern Coliseum, the narrative constructs a stratum of allusion that symbolizes the 
fulcrum of mundane power. The failure of Marching to Heaven represents the collapse of the biblical Tower of Babel with its ambition to defy divine authority. Tajirika's coliseum is reminiscent of the ancient Roman Coliseum and the fact that it is built on the same spot previously reserved for the construction of Marching to Heaven is a symbol of time-space that epitomizes the reversion that has come with Tajirika's accession to power and his attempt to capture both the antiquity and futurity of absolute power as contained in the oxymoronic use of "imperial democracy" above.

Even though En Attendant le Vote des Bêtes Sauvages and Wizard of the Crow preponderantly focus on the dark side of societies under dictatorships, the novels by the same token (but in different forms) strike notes of optimism. Both novels can still be posited as media of the quest for "an enabling beginning point and a vindicating goal" for societies that seem to be "enclosed by a circle" (Said 1994:26-27). In Wizard of the Crow, the refusal of the army to use force against the protesting crowd towards the end of the text symbolizes the turning over of a new page that defies the tradition of the past whereby the army obsequiously followed the orders of the autocrat against fellow citizens (Wizard, 645). The Movement for the Voice of the People re-appropriates the public sphere and turns it into a space for counteracting the demagogy and propaganda of the Ruler and his regime. The determination of the protesters to compel the Ruler to adopt democratic reforms also showcases a new wave of citizens' consciousness that cannot be underestimated. Though Tajirika's coup means a continuation and even a worsening of the dictatorial yoke, there is a growing civic consciousness and unity against oppression. This is conveyed through the strong bond between Kamiti and Nyawira. It is a symbol of love and political commitment that will bring to life a new future for the Republic of Aburiria. The Ruler is therefore not in charge of the future, a new world is opening before his eyes though his autocratic power blinkers his perception of the unfolding realities.

The idealistic representation of the heard-quarters of The Movement for the Voice of the People depicts an atmosphere of regeneration. The headquarters of the movement is located near the "forest", a chronotope of liberation and renewal. The narrator asserts that:

The forest was a school to which they always came to hear what it had to tell them: You take, you give, for if you only take without giving back, you will leave the giver exhausted into death. The gardens were nurseries for healing plants with seeds that could be planted on farms elsewhere; the healing of the land had to start somewhere. (Wizard, 758)

The forest imagery with its verdant surroundings symbolizes hope. It is a memory metaphor of the space for recovering traces of resistance, the rekindling of betrayed hopes and the reimagining of an alternative vision for Aburiria. Ngugi, in his traditional positivist bent, idealises the peasants as the architects of genuine change. This can be accounted for by the symbolic name of the heroine of the text, "Nyawira" which literally means in Gikuyu, "She who works". This is contrasted to the character "Tajirika" ("becoming rich"). As such the text is based on a Manichean clash of absolute qualities which evolves simultaneously in a conflictual plot. Though the germ of dictatorship seems to have triumphed in the short term, the future seems to elicit hope and opportunity incarnated by the Movement for the Voice of the People. On the other hand, Kourouma's irony bears a measure of skepticism to any note of idealization. His text is underlined by a deep suspicion of human nature and intent. Even characters whose subject status is depicted with pathos like the unemployed youth come under the same ironic gaze of the narrator as those who represent oppression like Koyaga and Maclédio. That notwithstanding, there is still a signal of hope in Kourouma's text. The introductory proverbs to the last part of the text illustrate this point: 
Au bout de la patience, il y a le ciel. (358)

(There is light at the end of the tunnel)

La nuit dure longtemps mais le jour finit par arriver. (358)

(The night may be long but the day will finally break)

The above proverbs underline the inevitability of change and the fact that even the dismal conditions expressed in the text are time-bound. It can therefore be said that the retrogressive progression deduced throughout Kourouma's text coexists with optimistic notes based on a "nomological-deductive" worldview (White 1973:12) of axiomatic, universal and inviolable truths. By ending with such proverbs that connote hope and change, the text positions itself as a prologue to events that are situated beyond its ambits, considering human conditions as definitely succumbed under the cosmic law of change and impermanence. In effect, his text functions within and is framed by traditional wisdom with its belief in hope, the background against which it is set.

\section{Note}

1-All translations are mine.

\section{References}

Bakhtin, mikhail. "forms of time and the chronotope in the novel: notes towards a historical poetics".15-24. Narrative dynamics: essays on time, plot, closure, and frames. Brian richardson (ed.) Columbus: ohio university press, 2002.

Bayart, jean-françois. Les etudes post-coloniales. Paris: karthala, 2010.

Bhabha, homi k. The location of culture: london and new york: routledge, 1994.

Bisanswa, justin k. "the adventures of the epic and novel in ahmadou kourouma's writings."Research in african literatures, vol. 38, no. 2 (summer, 2007), pp. 81-94. 27/01/2011.

Borgomano, madeleine. Des hommes ou des bêtes? Lecture d'en attendant le vote des bêtes sauvages d'ahmadou kourouma. Paris: l'harmattan, 2000.

Boulaga, fabien eboussi. Les conférences nationales en afrique noire. Paris: karthala, 1993.

Fox, robert elliot. “engaging ngugi research in african literatures,” vol. 34, no. 4 (winter, 2003), pp. $115-128$. 27/01/2011.<http://www.jstor.org/stable/4618331>.

Garnier, xavier. Corps et politique dans les litteratures d'afrique. Littératures francophones et politiques. Jean bessière, (ed). Paris: karthala, 2009. 10-21.

Indangasi, henry "ngugi's ideal reader and the postcolonial reality". The yearbook of english studies, vol. 27. The politics of postcolonial criticism (1997), pp. 193-200. 27/01/2011.

Kermode, frank. The sense of ending. London: oxford university press, 1968.

Kourouma, ahmadou. En attendant le vote des bêtes sauvages. Paris: seuil, 1998.

Koné, amadou. "discourse in kourouma's novels: writing two languages to translate two realities”. Research in african literatures. Vol. 38, no. 2 (summer, 2007), pp. 109-123. 27/01/2011.

Loomba, ania. Colonialism and post-colonialism. London /new york: routledge, 1998.

Mcclintock, anne. "the angel of progress: pitfalls of the term 'postcolonialism' "(1992) in african literature:an anthology of criticism and theory. Eds. Tejumola olaniyan and ato quayson. Malden: blackwell publishers, 2010. 628-636

Mbembe, achille. De la postcolonie: essai sur l'imagination politique dans l'afrique contemporaine. Paris: karthala, 2000 .

Ndiaye, christiane. "kourouma, the myth: the rhetoric of the commonplace in kourouma criticism". Research in african literatures, vol. 38, no. 2 (summer, 2007), pp. 95-108.

Ngugi wa thiong'o. Wizard of the crow. New york: pantheon books, 2006. 
Priebe, richard k. "literature, community, and violence: reading african literature in the west, post-9/11 author(s)" research in african literatures, vol. 36, no. 2 (summer, 2005), pp. 46-58.

Said,w edward. Culture and imperialism. New york: alfred a knopf, 1994.

White, hayden. Meta-history: the historical imagination in nineteenth century europe. Baltimore and london: john hopkins university press, 1973. 